\title{
TNFa sensitizes neuroblastoma cells to FasL-, cisplatin- and etoposide-induced cell death by NF-KB-mediated expression of Fas
}

Koen MO Galenkamp ${ }^{1}$, Paulina Carriba ${ }^{1}$, Jorge Urresti ${ }^{1}$, Laura Planells-Ferrer ${ }^{1}$, Elena Coccia ${ }^{1}$, Joaquín Lopez-Soriano ${ }^{1}$, Bruna Barneda-Zahonero', Rana S Moubarak', Miguel F Segura ${ }^{2^{*}}$ and Joan X Comella ${ }^{1^{*}}$

\begin{abstract}
Background: Patients with high-risk neuroblastoma (NBL) tumors have a high mortality rate. Consequently, there is an urgent need for the development of new treatments for this condition. Targeting death receptor signaling has been proposed as an alternative to standard chemo- and radio-therapies in various tumors. In NBL, this therapeutic strategy has been largely disregarded, possibly because $\sim 50-70 \%$ of all human NBLs are characterized by caspase-8 silencing. However, the expression of caspase-8 is detected in a significant group of NBL patients, and they could therefore benefit from treatments that induce cell death through death receptor activation. Given that cytokines, such as TNFa, are able to upregulate Fas expression, we sought to address the therapeutic relevance of co-treatment with TNFa and FasL in NBL.
\end{abstract}

Methods: For the purpose of the study we used a set of eight NBL cell lines. Here we explore the cell death induced by TNFa, FasL, cisplatin, and etoposide, or a combination thereof by Hoechst staining and calcein viability assay. Further assessment of the signaling pathways involved was performed by caspase activity assays and Western blot experiments. Characterization of Fas expression levels was achieved by qRT-PCR, cell surface biotinylation assays, and cytometry.

Results: We have found that TNFa is able to increase FasL-induced cell death by a mechanism that involves the NF-KB-mediated induction of the Fas receptor. Moreover, TNFa sensitized NBL cells to DNA-damaging agents (i.e. cisplatin and etoposide) that induce the expression of FasL. Priming to FasL-, cisplatin-, and etoposide-induced cell death could only be achieved in NBLs that display TNFa-induced upregulation of Fas. Further analysis denotes that the high degree of heterogeneity between NBLs is also manifested in Fas expression and modulation thereof by TNFa.

Conclusions: In summary, our findings reveal that TNFa sensitizes NBL cells to FasL-induced cell death by NF-kB-mediated upregulation of Fas and unveil a new mechanism through which TNFa enhances the efficacy of currently used NBL treatments, cisplatin and etoposide.

Keywords: Neuroblastoma, Fas (CD95/APO-1), TNFa, NF-kB, Cisplatin, Etoposide, Apoptosis

\footnotetext{
*Correspondence: miguel.segura@vhir.org; joan.comella@vhir.org

${ }^{1}$ Cell Signaling and Apoptosis Group, Fundacio Institut de Recerca de I'Hospital Universitari de la Vall d'Hebron, Edifici Collserola, Passeig Vall d'Hebron 119-129, 08035 Barcelona, Spain

2Laboratory of Translational Research in Pediatric Cancer, Fundacio Institut de Recerca de l'Hospital Universitari de la Vall d'Hebron, Edifici Collserola,

Passeig Vall d'Hebron 119-129, 08035 Barcelona, Spain
} 


\section{Background}

Neuroblastoma (NBL) is a solid tumor that arises from neuronal crest cells of the sympathetic nervous system. The most common form of cancer in infancy, NBL causes $15 \%$ of cancer-related deaths in children. The tumors have remarkable heterogeneity, which become evident in the clinic where patients can show spontaneous regression or rapid and fatal tumor progression. Over the years, significant advances have been made in the treatment of low- and intermediate-risk patients, thus allowing reaching high survival rates; however, the 5 -year survival rate of patients in the high-risk group is still below 50\% [1-3].

High-risk NBLs are treated with surgery, chemotherapy, radiotherapy, and/or the use of biological agents. Most of the therapeutic strategies used in NBL interfere with cell cycle progression and DNA synthesis or function, thereby causing DNA damage and the induction of apoptosis through the intrinsic and extrinsic apoptotic pathways [4].

The extrinsic or Death receptor (DR) pathway is activated by cell surface receptors of the tumor necrosis factor receptor (TNFR) family, which includes receptors for TNF $\alpha$, FasL, and TNF-related apoptosis-inducing ligand (TRAIL) [5-7]. These receptors contain a death domain in their cytosolic tail which upon receptor activation leads to context-dependent outcomes such as apoptosis, necroptosis, or pro-survival signaling. The targeting of DR signaling has been proposed and studied for the treatment of various types of cancers [8-10]. For NBL tumors, this strategy has been largely disregarded, possibly because caspase- 8 silencing occurs in $50-70 \%$ of all human NBLs [11-14]. However, a significant group of NBL patients do express caspase- 8 and could benefit from treatments that induce DR activation. Given that TNFo is able to upregulate Fas expression in human cancer cell lines and sensitize them to FasL-induced cell death [15-17], we sought to investigate whether TNFa and FasL combination could be therapeutically relevant in NBL.

We found that TNF $\alpha$ treatment primes a subset of NBLs for FasL-induced cell death by triggering the NF$\kappa B$-mediated upregulation of Fas. Moreover, TNF $\alpha$ pretreatment increased cisplatin- and etoposide-induced caspase- 8 cleavage and cell death in NBL cells that express both Fas and caspase- 8 . Our findings suggest that selected NBL patients could benefit from treatments that target TNFR1 and upregulate Fas expression.

\section{Results}

\section{TNFa and FasL co-treatment induces cell death in} SK-N-AS cells

To ascertain whether simultaneous treatment with FasL and TNF $\alpha$ induces cell death in NBL cells, we used the caspase-8-expressing NBL cell line SK-N-AS. TNFR1 was activated with soluble TNFa and the Fas receptor with trimeric Fc:hFasL [18-20]. Cell death assessment by Hoechst staining showed that TNF $\alpha$ or FasL treatment alone barely induced cell death $(\sim 5 \%$ and $20 \%$ respectively). However, the combination of the two cytokines caused an increase in cell death after $8 \mathrm{~h}$ of treatment, as compared to treatment with TNF $\alpha$ or FasL alone (Figure 1A). After $24 \mathrm{~h}$, nearly all cells in the co-treatment condition were dead. Moreover, an increase in caspase-8 and caspase- $3 / 7$ activity was observed after simultaneous treatment with TNF $\alpha$ and FasL (Figure 1B-C). The use of the caspase-8 specific inhibitor IETD or the pan-caspase inhibitor QVD fully abrogated TNF $\alpha /$ FasL-induced cell death, thereby indicating that apoptosis triggered by FasL is the main mechanism of loss of viability (Figure 1D).

\section{TNFa primes SK-N-AS cells for FasL-induced cell death by upregulating Fas}

Next, we analyzed whether the phenotypic effects of the TNF $\alpha /$ FasL co-treatment were caused by the FasL and TNF $\alpha$ receptors signaling in synergy or whether one DR was sensitizing for apoptotic signaling by the other DR. Sequential treatment with TNF $\alpha$ or FasL followed by FasL or TNF $\alpha$ administration, respectively, revealed that TNF $\alpha$ was able to sensitize SK-N-AS cells to FasLinduced cell death (Figure 2A). On the contrary, FasL pre-treatment did not sensitize the cells to TNFa. The increase in caspase- 8 activity during the co-treatment and the abrogation of cell death when using the caspase8 inhibitor IETD suggested that TNF $\alpha$ induces molecular changes upstream of caspase- 8 activation. Therefore, to address this point, we characterized the effects of TNFa on the expression of various components of the DISC complex (Figure 2B). Interestingly, a significant increase was observed only in Fas mRNA levels whereas minimal variations were detected for caspase-8, FADD, and RIP1 (Figure 2B). The increase in Fas mRNA levels was confirmed at the protein level by Western blot as early as $8 \mathrm{~h}$ after TNF $\alpha$ treatment (Figure 2C), which is consistent with the increase in cell death observed after simultaneous treatment with TNF $\alpha$ and FasL.

\section{Newly synthesized Fas is exposed to the plasma membrane and favors DISC formation}

The increase in FasL-mediated cell death could be explained by exposure of the newly synthesized Fas receptor to the cell surface. To test this notion, we used a cell surface biotinylation assay to analyze the cellular distribution of Fas after TNF $\alpha$ treatment. An increase in total and cell surface Fas was already observed after $4 \mathrm{~h}$ of TNF $\alpha$ treatment, peaking at $12 \mathrm{~h}$, after which the expression was maintained for at least another $12 \mathrm{~h}$ (Figure 3A). To further confirm the functionality of the 


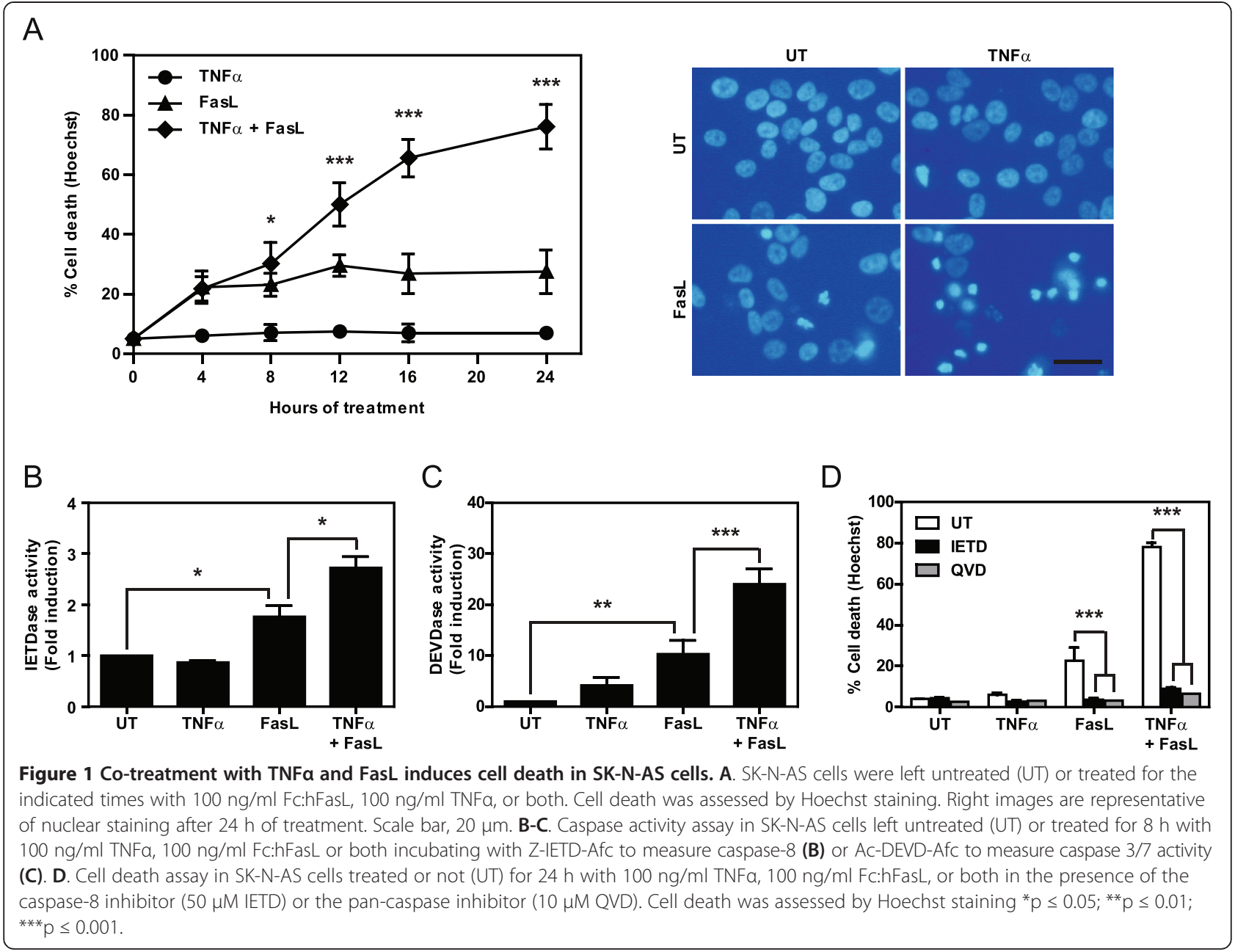

newly synthesized Fas, a DISC formation assay was performed before and after TNF $\alpha$ pre-treatment. Indeed, FasL co-immunoprecipitated with FADD and caspase- 8 only in cells pre-treated with TNF $\alpha$ (Figure 3B). Interestingly, in the absence of this pre-treatment, we were only able to immunoprecipitate low levels of high molecular weight Fas $(\sim 150 \mathrm{kDa})$ and in these conditions we did not detect caspase-8 or FADD immunoprecipitation. The analysis of input cell lysates confirmed that caspase8 and -3 were cleaved only after FasL treatment and could be increased by TNF $\alpha$ pre-treatment (Figure 3B). These data demonstrate that cell surface exposure of Fas shows similar kinetics as the newly synthesized Fas, thereby suggesting a rapid translocation of newly synthesized Fas to the surface. Furthermore, the increased cell surface expression of Fas enhanced FasL-induced DISC formation, which led to the activation of the extrinsic apoptotic pathway.

TNFa-induced Fas is transcriptionally regulated by NF-KB TNF $\alpha$ has been shown to induce gene expression by activating various signaling pathways, such as those of
ERK1/2, PI3K, and JNK kinases and transcription factors like NF- $\mathrm{B}[5,6,21]$. Therefore, we proceeded to analyze Fas expression after TNF $\alpha$ treatment combined with specific inhibitors: PD98059 (ERK1/2), LY294002 (PI3K), SP600125 (JNK), BAY 11-7082 (NF-kB), or overexpressing Super Repressor (SR), a mutated form of the NF- $k B$ inhibitor І $\mathrm{\kappa} \mathrm{B} \alpha$ that inhibits NF- $\mathrm{KB}$ signaling [22,23]. While the inhibition of ERK1/2, PI3K or JNK did not block the upregulation of Fas by TNF $\alpha$ (Figure 4A), the inhibition of the NF-kB -pathway by overexpression of SR or treatment with BAY 11-7082 did fully abrogate the upregulation of Fas induced by TNF $\alpha$ at the protein level (Figure 4B). Other known NF-kB targets, such as Bcl-2 [24] and c-FLIP ${ }_{S}$ [25], were used as controls. Moreover, the use of SR overexpression or treatment with BAY 11-7082 blocked the TNF $\alpha$-induced upregulation of Fas mRNA or known NF- $\mathrm{kB}$ targets such as c-FLIP and Bcl-2 (Figure 4C). Further assessment of TNF $\alpha$-induced gene transcription and mRNA translation was performed with the use of DNA transcription (Actinomycin D) and mRNA translation (Cycloheximide) inhibitors (Figure 4D-E). Both inhibitors blocked the 


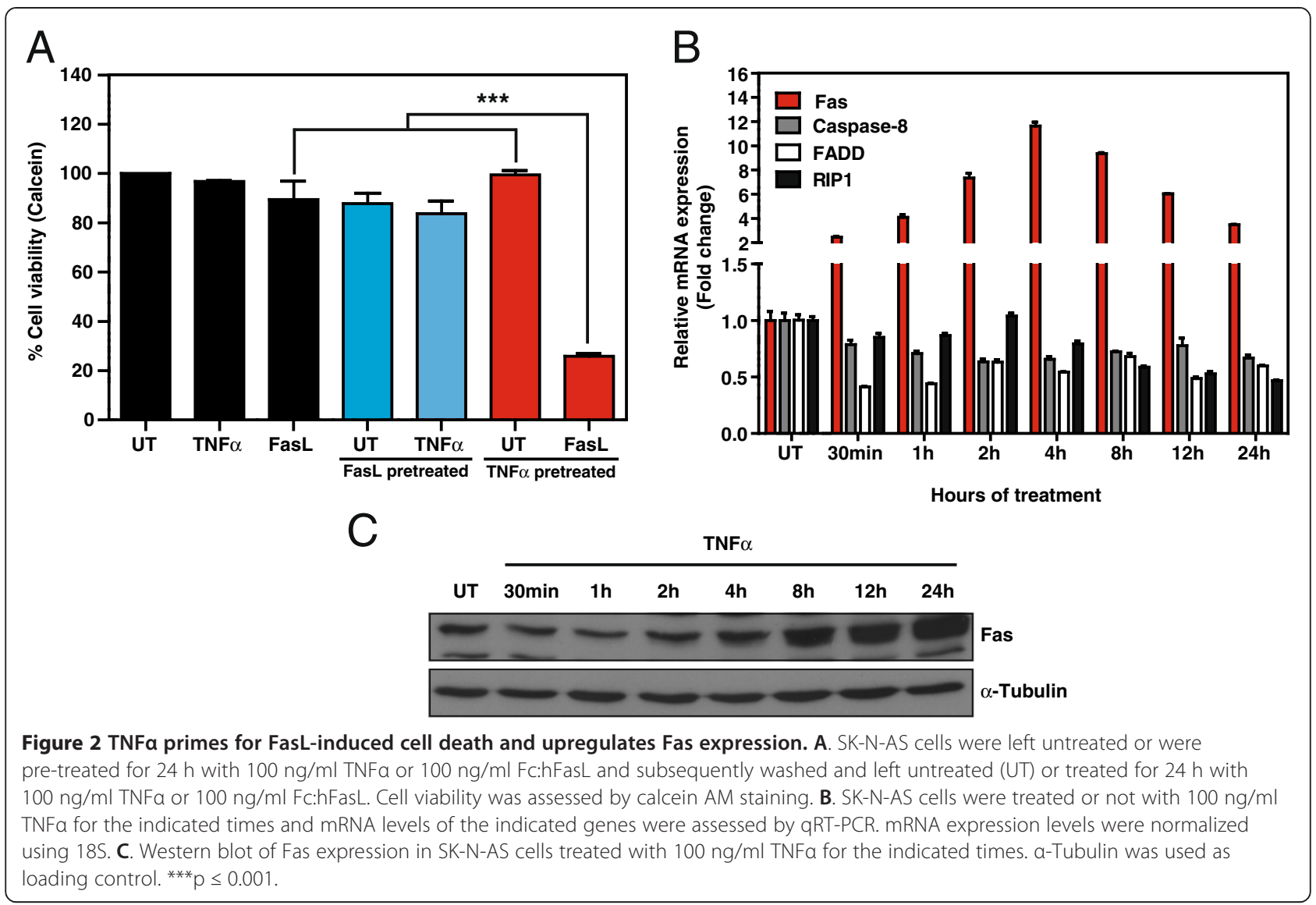

upregulation of Fas protein levels induced by TNF $\alpha$, whereas only actinomycin D was able to inhibit TNF $\alpha$ induced upregulation of Fas mRNA. Cycloheximide did not result in abrogation of Fas mRNA induction, thereby confirming the direct NF- $\mathrm{kB}$-mediated transcriptional regulation of this protein (Figure 4D-E). In summary, our results reveal that the upregulation of Fas mRNA occurs rapidly after TNF $\alpha$ treatment through activation of the NF- $\mathrm{kB}$-mediated transcription of the Fas gene. Moreover, the inhibition of Fas upregulation by the overexpression of SR, treatment with BAY 11-7082 (Figure 4B), or by blocking its synthesis with actinomycin $\mathrm{D}$ and cycloheximide treatment (Figure 4E) prevented the cell surface exposure of Fas.

TNFa primes for cisplatin- and etoposide-induced activation of caspase- 8 and cell death

The FasL/Fas system has been shown to participate in cell death mechanisms triggered by DNA-damaging agents currently used in NBL therapy such as cisplatin and etoposide [26,27]. Therefore, we addressed whether TNF $\alpha$ treatment enhances the cytotoxic effect of these two drugs. Cisplatin and etoposide have been shown to induce FasL expression in NBL cells [27]. We confirmed these observations in SK-N-AS cells, as an increase in
FasL mRNA was detected after $24 \mathrm{~h}$ of etoposide or cisplatin treatment (Figure 5A). Furthermore, the induction of FasL by treatment with these chemotherapeutic agents concurred with the activation of caspase-8, as reflected by caspase- 8 cleavage (Figure 5B). Indeed, TNF $\alpha$ treatment upregulated Fas expression in SK-N-AS cells and enhanced the cleavage of caspase- 8 induced by cisplatin (Figure 5B left) and by etoposide (Figure 5B right). We next analyzed the functional consequences of these observations in a subset of NBL cell lines (SK-NAS, SK-N-SH, SH-SY5Y, and LAI-5S) and assessed cell death by Hoechst staining (Figure $5 \mathrm{C}$ ). Notably, only the SK-N-AS and SK-N-SH cell lines showed an increase in cisplatin- and etoposide-induced cell death when primed with TNF $\alpha$, whereas no changes in cell death were observed for the SH-SY5Y and LAI-5S cell lines.

NBLs show heterogeneity in TNFa-induced Fas expression, thereby explaining the priming for cisplatin- and etoposide-induced cell death

NBLs are known to have a high degree of heterogeneity [1-3], which may explain why some NBL cell lines are not primed by TNF $\alpha$ for cisplatin- and etoposideinduced cell death. Therefore, we assessed the expression of Fas and its modulation by TNF $\alpha$ treatment in a 


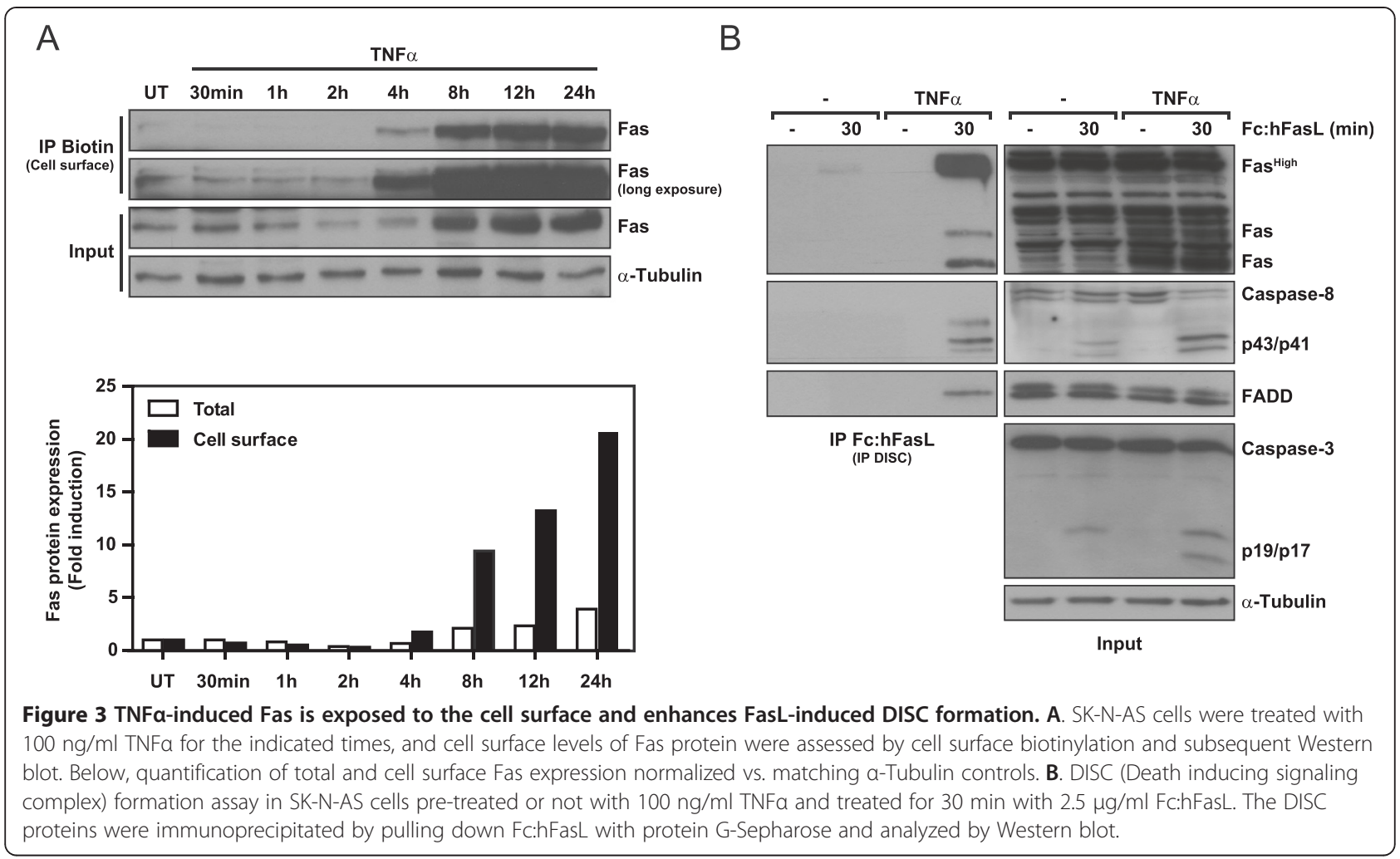

set of eight NBL cell lines. In addition to the SK-N-AS cell line, TNF $\alpha$ upregulated Fas expression in the SK-N-SH, CHLA90, and Tet21N cell lines, as observed by flow cytometry (Figure 6A) and Western blot (Figure 6B). Furthermore, TNF $\alpha$ was also able to sensitize these cells to FasL-induced apoptosis, as determined by Hoechst staining (Figure 6C) and caspase-3/7 activity (Additional file 1: Figure S1). In contrast, the SH-SY5Y, LAI-5S, IMR32, and SK-N-BE(2) cell lines did not show changes in Fas expression (Figure 6A-B), FasL-induced cell death (Figure 6C), or caspase-3/7 activity (Additional file 1: Figure S1) after $\mathrm{TNF} \alpha$ treatment. Interestingly, these cells showed TNF $\alpha-$ induced $\mathrm{I}_{\kappa} \mathrm{B} \alpha$ degradation and the upregulation of other known NF- $\mathrm{kB}$-target genes, such as Bcl-2 [24] and/or cIAP2 [28] (Additional file 2: Figure S2A-B).

A correlation could be observed between the expression of both Fas and caspase-8, the induction of cell death by FasL and the sensitization thereof by TNF $\alpha$. Cells that only express one of the two proteins did not show FasL-induced cell death and could not be sensitized by TNF $\alpha$. However, cells that express both proteins, Fas and caspase-8, did show FasL-induced cell death and TNF $\alpha$-induced sensitization. Furthermore, the levels of Fas and caspase- 8 expression concur with the FasL-induced cell death response. CHLA90 cells, with low levels of Fas and caspase-8, exhibit little FasLinduced cell death when compared to Tet $21 \mathrm{~N}$ cells, which show high levels of Fas and caspase- 8 expression.
Due to these high levels and the corresponding cell death response, Tet $21 \mathrm{~N}$ cells had to be treated with lower levels of FasL for the TNF $\alpha$-induced sensitization to become apparent, since $100 \mathrm{ng} / \mathrm{ml}$ FasL induced a near complete cell death response (data no shown).

These findings demonstrate that although NF- $\mathrm{kB}$ is activated and induces gene transcription in all the NBL cell lines studied here, there is a subset of NBL cell lines in which Fas expression is not upregulated in response to TNF $\alpha$ treatment. These observations concur with our previous observations in which we determined that these cells were primed neither for cisplatin- nor etoposideinduced cell death when targeted with TNF $\alpha$.

\section{Interferon- $\gamma$ reconstitutes caspase-8, upregulates Fas} expression, and primes NBL for FasL-induced cell death Interferon- $\gamma($ IFN $\gamma$ ) is known to render NBL cells sensitive to FasL-induced cell death by reconstituting caspase- 8 and upregulating Fas expression [29-31]. Here we studied whether NBL treatment with IFNy promotes TNF $\alpha-$ induced Fas expression in cell lines that previously did not show Fas induction in response to TNF $\alpha$ treatment (i.e. SH-SY5Y and SK-N-BE(2)). We confirmed that IFNY upregulates caspase- 8 and Fas expression in these cell lines (Figure 7A-B). The SK-N-BE(2) cell line showed a TNF $\alpha$-induced increase in caspase- 8 and Fas expression after IFN $\gamma$ treatment. However, in the SH-SY5Y cells, TNF $\alpha$ did not modulate the expression of either protein. 


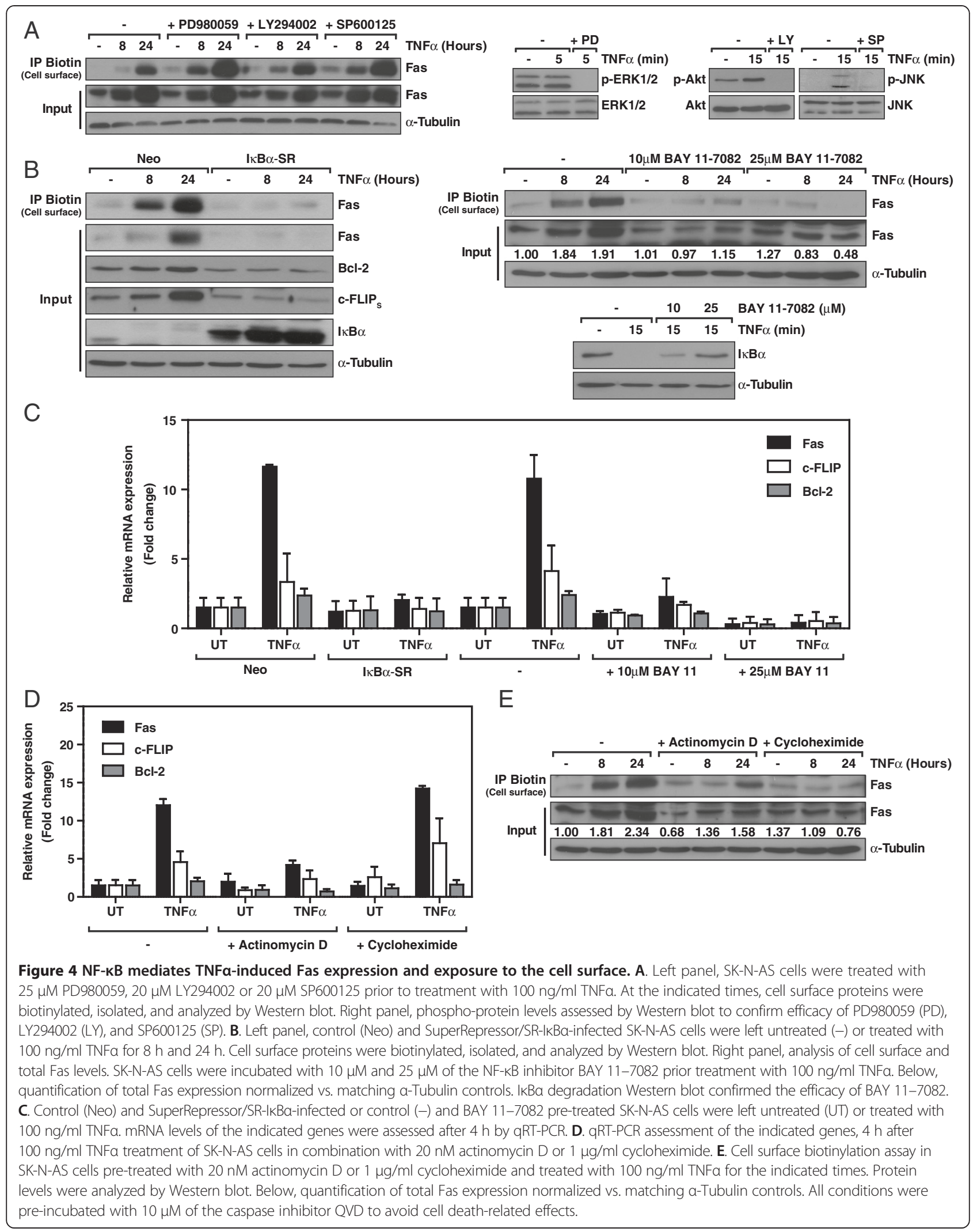




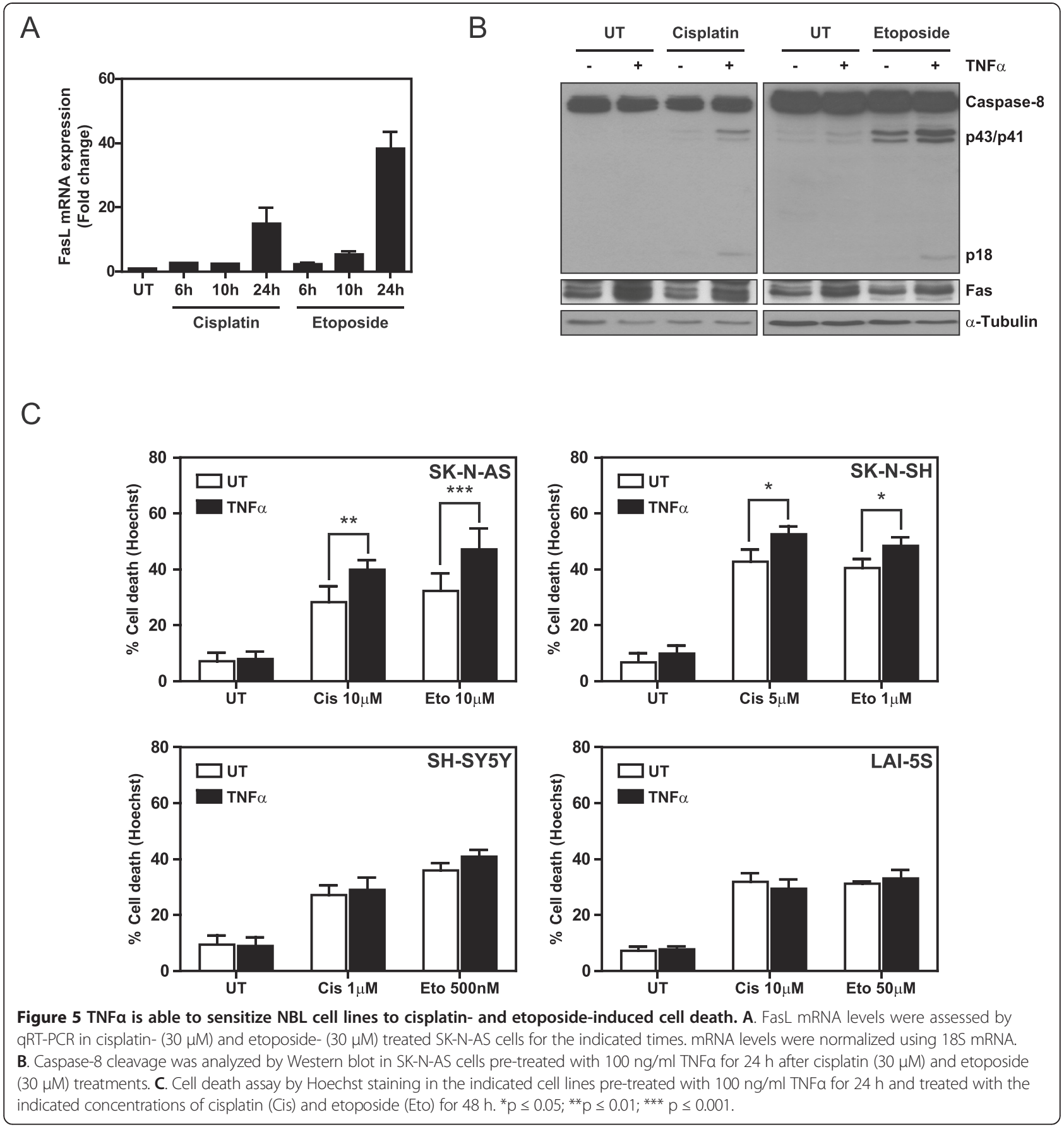

According to these observations, IFN $\gamma$ sensitized SK-N$\mathrm{BE}(2)$ and SH-SY5Y cells to FasL-induced cell death (Figure $7 \mathrm{C}$ ) and caspase $3 / 7$ activity (Additional file 1: Figure S1). For the SK-N-BE(2) cells, subsequent TNF $\alpha$ treatment further increased sensitization to FasL-induced cell death. In contrast, SH-SY5Y cells, which did not show a further increase in caspase- 8 or Fas levels, did not show further sensitization to FasL-induced cell death after stimulation with TNF $\alpha$. These data indicate that the induction of Fas expression by TNF $\alpha$ in NBLs cannot always be recovered by IFN $\gamma$ treatment, thus pointing to different levels of Fas regulation.

\section{Discussion}

Many patients with high-risk NBL tumors continue to have a poor prognosis. Consequently, ongoing efforts are being channeled into the development of new treatments or the discovery of therapeutic agents that can increase the efficacy of current clinical regimes-cisplatin and etoposide being examples of such drugs [2]. Here 

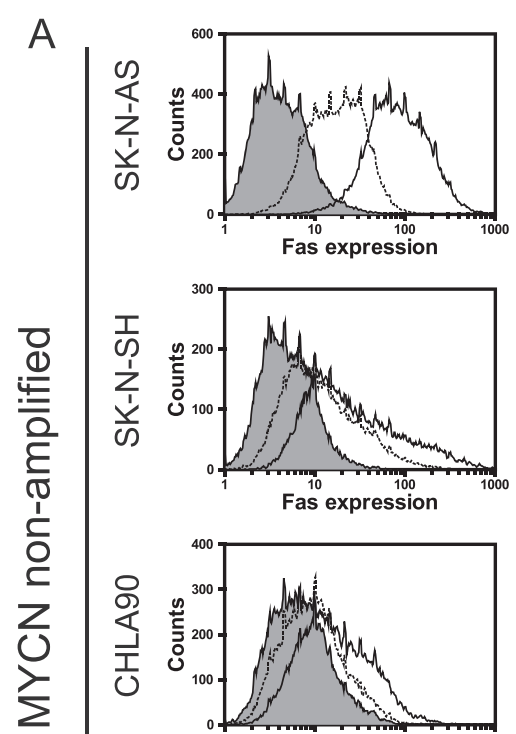

B
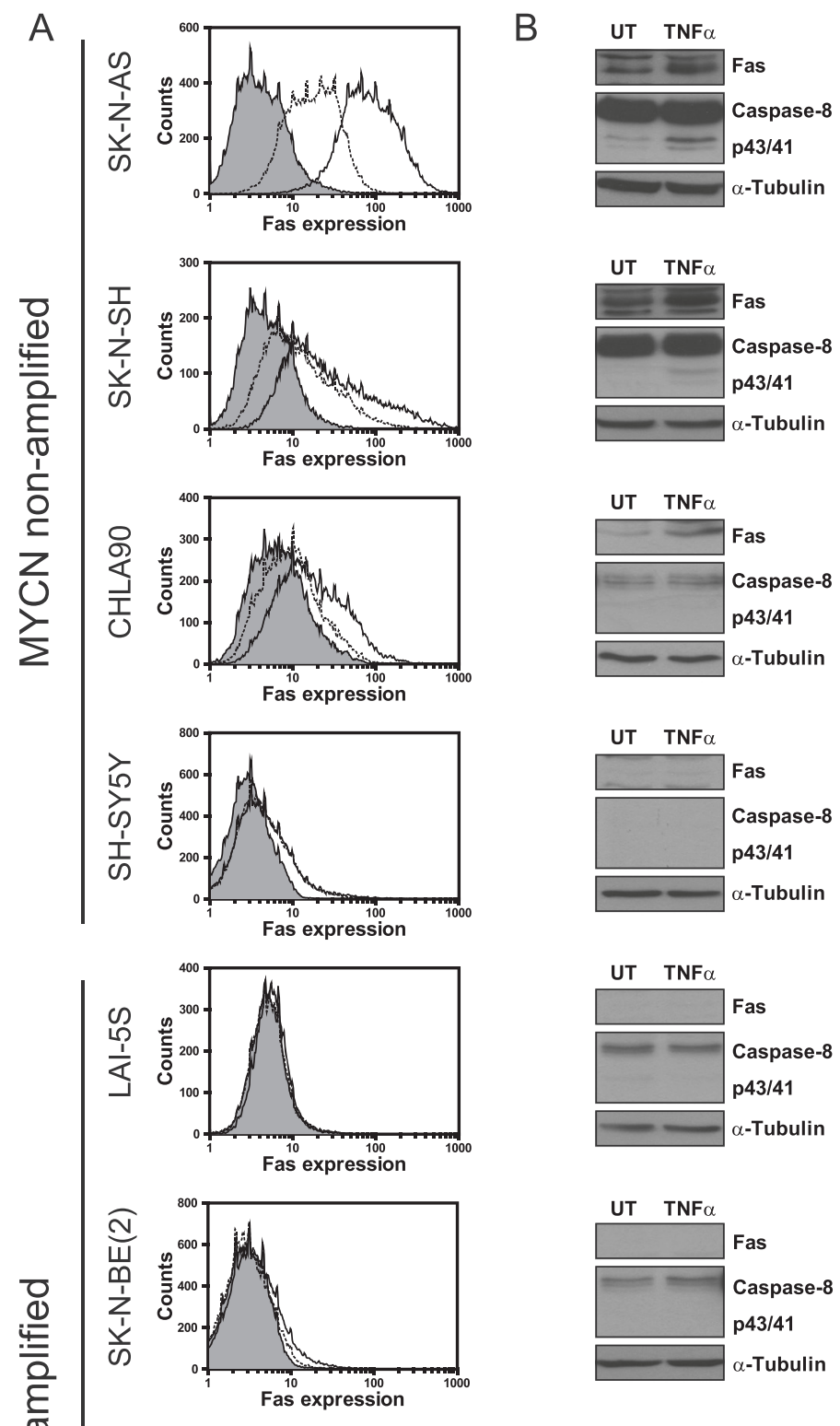

$\sum_{z}^{\bar{Z}}$
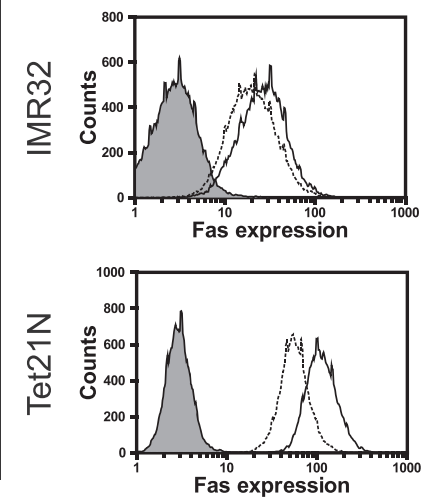

— Iso -..- UT - TNF $\alpha$

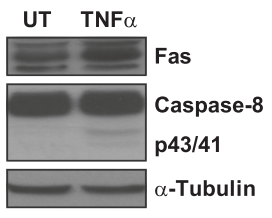

UT TNF $\alpha$

C
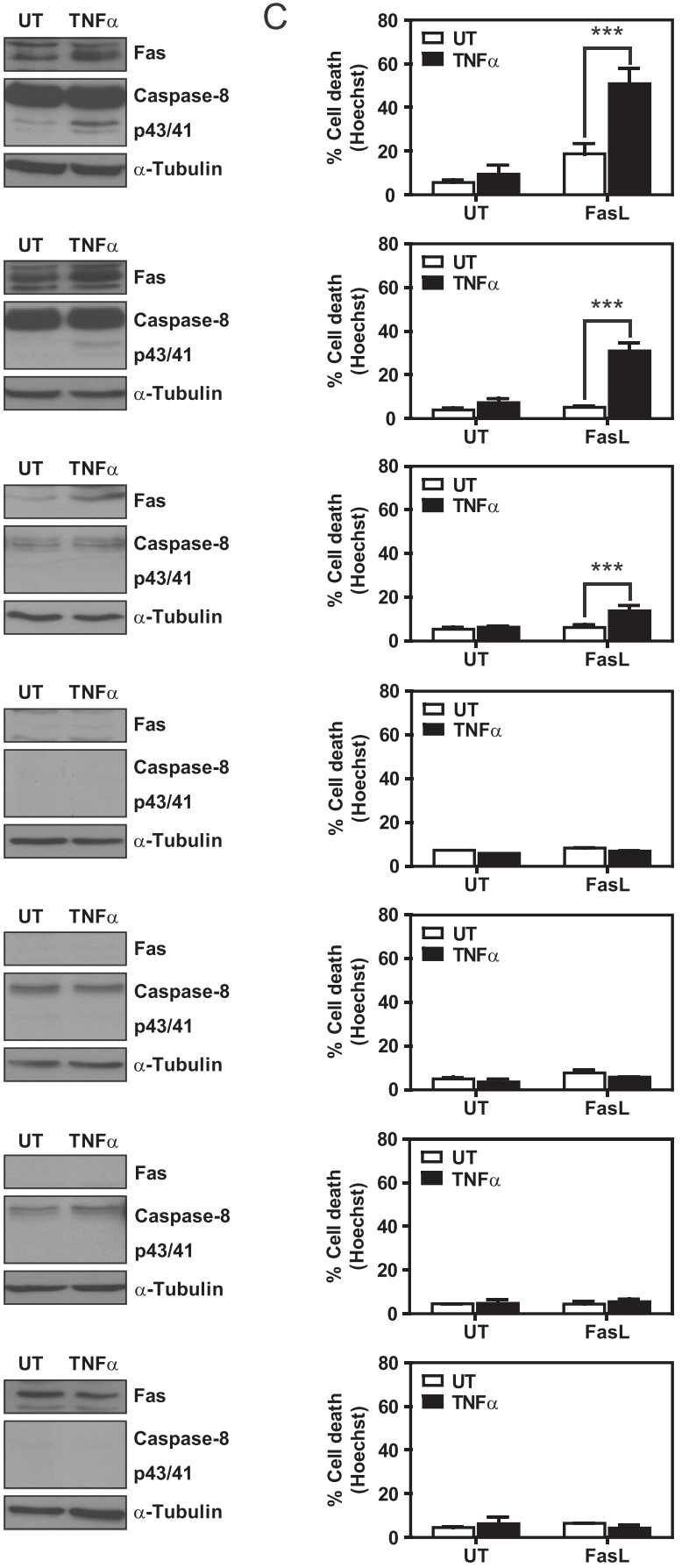

UT TNF $\alpha$
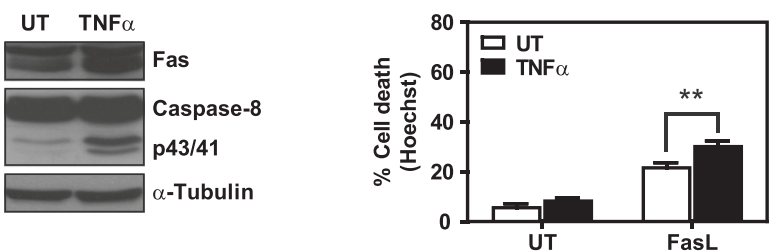

Figure 6 (See legend on next page.) 
(See figure on previous page.)

Figure 6 NBLs show heterogeneous Fas expression in response to TNFa treatment. A. NBL cell lines were treated with $100 \mathrm{ng} / \mathrm{ml}$ TNFa or left untreated (UT) for $24 \mathrm{~h}$. Fas expression was analyzed by cytometry using a PE-conjugated Fas or isotype antibody. B. Cells were treated for $24 \mathrm{~h}$ with $100 \mathrm{ng} / \mathrm{ml}$ TNFa or were left untreated (UT). Protein expression levels were analyzed by Western blot. C. Cell death assay by Hoechst staining in the indicated cell lines pre-treated with $100 \mathrm{ng} / \mathrm{ml}$ TNFa for $24 \mathrm{~h}$ and treated for another $24 \mathrm{~h}$ with $100 \mathrm{ng} / \mathrm{ml} \mathrm{Fc:hFasL,} \mathrm{or} 1 \mathrm{ng} / \mathrm{ml}$ Fc:hFasL for Tet21N cells. ${ }^{* *} p \leq 0.01 ;{ }^{* *} p \leq 0.001$.

we describe that the activation of TNFR1 increases susceptibility to FasL-, cisplatin- and etoposide-induced cell death through the NF- $\mathrm{kB}$-mediated upregulation of Fas, a target that has received little attention for NBL therapies. The newly synthesized Fas is exposed to the cell surface and incorporated into the DISC complex upon ligand binding, thereby triggering the activation of caspases and inducing apoptotic cell death.

Soluble TNF $\alpha$ exerts its effects through the binding and activation of the ubiquitously expressed TNFR1 receptor $[5-7,18,19]$. Depending on the cellular context, TNF $\alpha$ stimulation induces apoptosis, necroptosis, or prosurvival signaling through the activation of caspases, kinases, and transcription factors such as NF- $\mathrm{kB}[5-7,21]$. For NF- $\mathrm{kB}$ activation, TNFR1 binds the adaptor protein TRADD through interaction with its death domain. This interaction allows the recruitment of the adapter protein RIP1 and the E3 ligases TRAF2/5 and cIAP1/2, thereby inducing the ubiquitination of RIP1. This shapes the platform for recruitment and activation of the IKK complex that induces phosphorylation of the cytoplasmic NF- $\mathrm{BB}$ inhibitor I $\mathrm{I} B \alpha$, thereby targeting it for ubiquitination and subsequent proteasomal degradation. Degradation of I $\mathrm{K} B \alpha$ mediates the release of NF- $\mathrm{KB}$ and allows its translocation to the nucleus where it can induce gene transcription. According to our data and data from others, $F A S$ is amongst the genes that can be induced by NF-kB. Chan et al. and Liu et al. have previously identified the p65/RelA binding site in the Fas promoter and confirmed TNF $\alpha$-induced $\mathrm{NF}-\mathrm{kB}$-mediated upregulation of Fas [32,33]. Here, we were able to demonstrate the NF- $\mathrm{kB}$-mediated regulation in NBLs and discarded regulation of Fas expression by other pathways known to be activated by TNFR1 (i.e. ERK1/2, PI3K, and JNK).

Given the participation of the Fas/FasL system in the mechanisms of cell death caused by DNA-damaging agents such as cisplatin and etoposide [26,27], we studied the possibility of improving the efficacy of these drugs by combined treatment with TNF $\alpha$. Our results showed that TNFa pre-treatment increased cisplatinand etoposide-induced cell death in two of the four NBL cell lines studied. Similarly, Benedetti et al. reported that TNF $\alpha$ acts in synergy with cisplatin in renal proximal tubular cells, inducing an increase in cell death by prolonging JNK activation and inhibiting NF- $\mathrm{KB}$ translocation to the nucleus [34,35]. However, our data
A

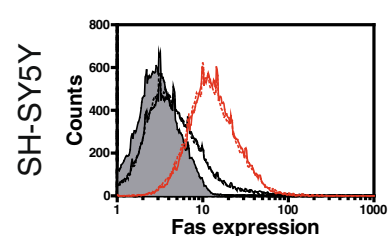

— Iso -..- UT — TNF $\alpha$

- IFN $\gamma$--- IFN $\gamma-T$ TNF $\alpha$

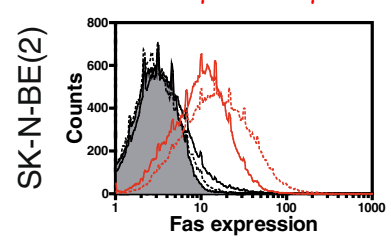

B
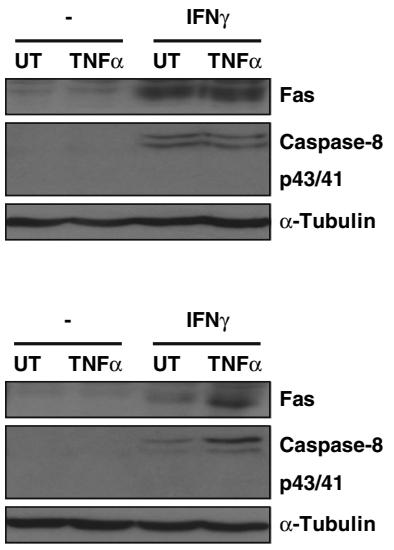

C
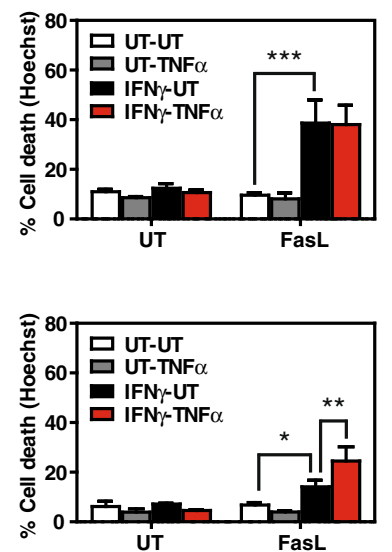

Figure 7 IFN renders caspase-8- and Fas-deficient NBLs sensitive to FasL. A. The indicated cell lines were treated with $100 \mathrm{ng} / \mathrm{ml}$ interferon- $\gamma$ (IFNY) or were left untreated (UT) for $24 \mathrm{~h}$. Cells were then treated or not for $24 \mathrm{~h}$ with $100 \mathrm{ng} / \mathrm{ml}$ TNFa and Fas expression was analyzed by cytometry using a PE-conjugated Fas or an isotype antibody. B. Fas and caspase-8 expression analysis by Western blot in the indicated cell lines pre-treated for $24 \mathrm{~h}$ with $100 \mathrm{ng} / \mathrm{ml}$ interferon- $\gamma$ (IFNY) and treated with $100 \mathrm{ng} / \mathrm{ml}$ TNFa for $24 \mathrm{~h}$. C. Cell death assay in NBL cell lines pre-treated or not (UT) with $100 \mathrm{ng} / \mathrm{ml} \mathrm{IFNy}$ for $24 \mathrm{~h}$ and thereafter treated or not with $100 \mathrm{ng} / \mathrm{ml}$ TNFa for $24 \mathrm{~h}$. Next, cells were treated for an additional $24 \mathrm{~h}$ with $100 \mathrm{ng} / \mathrm{ml}$ Fc:hFasL. ${ }^{*} p \leq 0.05 ;{ }^{* *} p \leq 0.01 ;{ }^{* * *} p \leq 0.001$. 
indicate that the TNF $\alpha$-induced priming for cisplatin- and etoposide-induced cell death depends on NF- $\mathrm{kB}$-mediated induction of Fas expression and caspase-8 cleavage.

Remarkably, not all the NBL cell lines studied were primed by TNF $\alpha$ for cisplatin- and etoposide-induced cell death. To predict the benefit of the TNF $\alpha$ combination therapy, we analyzed the expression of Fas and the modulation thereof by TNF $\alpha$ in a set of eight NBL cell lines. In four of the eight NBL cell lines, TNF $\alpha$ upregulated Fas expression. Furthermore, we observed that only the cell lines that showed TNF $\alpha$-induced upregulation of Fas expression also displayed TNFa-induced priming to FasL-, cisplatin-, and etoposide-induced cell death. The cell lines that showed TNF $\alpha$-induced priming also displayed Fas and caspase- 8 expression, whereas cell lines that were not primed by TNF $\alpha$ showed the expression of only one of the two proteins. The response to TNF $\alpha$ treatment was not related to other frequent NBL alterations, such as MYCN amplification or p53 functional status (see Table 1).

The mechanism by which Fas is silenced in NBL and why some cell lines do not respond to the TNF $\alpha-$ induced Fas regulation remains to be clarified. In the NBL cell lines addressed, we confirmed NF- $\mathrm{kB}$ activation after TNF $\alpha$ treatment and detected the induction of other known NF-kB target genes, such as cIAP2 and Bcl-2 [24,28]. One possible mechanism to explain this lack of Fas induction is that TNF $\alpha$ treatment stimulates the formation of different NF- $\mathrm{kB}$ heterodimers or NF- $\mathrm{kB}$ was post-transcriptionally modified, which may drive specific gene expression [42]. An alternative mechanism to account for the incapacity of TNF $\alpha$ to induce Fas expression can be found at the level of epigenetic regulation of the Fas gene. Methylation of the Fas promoter has been reported in various types of tumors, including NBL [43-45]. IFN $\gamma$ has been shown to restore caspase-8 and Fas expression in NBL cells [29-31,46,47] and to render them sensitive to FasL treatment. Consequently, IFN $\gamma$ may also prime caspase-8- or Fas-deficient NBL cells for the TNF $\alpha$ combination therapy. Indeed, we confirmed that IFNY primes these NBL cells for FasL- induced cell death. However, IFNY treatment did not sensitize all the NBL cell lines to the TNF $\alpha$-induced upregulation of Fas. These findings suggest that the expression of Fas in NBLs is regulated at various levels and that it differs between NBLs.

Recent studies have described the benefits of TNF $\alpha$ in combination with doxorubicin [48] or melphalan [49] for the treatment of solid tumors. Due to its low toleration in systemic treatment, various TNF $\alpha$ fusion proteins have been developed for localized treatment [50], some of which show promise and have entered clinical trials $[49,51,52]$. These findings break ground for the use of TNF $\alpha$ in the treatment of NBL in combination with cisplatin and etoposide.

Our results suggest that NF- $\mathrm{B} B$-mediated upregulation of Fas by TNF $\alpha$ could be a new approach for the treatment of NBL patients. These findings are in contradiction to the current dogma in which NF- $k B$ inhibition is seen as a strategy for cancer treatment, since NF- $\mathrm{kB}$ has been implicated in promoting cancer initiation, development, and metastasis $[53,54]$. NF- $\mathrm{kB}$ activation is known to promote cell survival by upregulating antiapoptotic proteins, such as Bcl-2, c-FLIP, and cIAP2 thereby inhibiting DR-induced apoptosis $[24,25,28]$. However, NF- $\mathrm{KB}$ is also able to promote apoptosis through the induction of pro-apoptotic proteins, such as Fas [32,33], Bax [55], DR5 [56], and DR6 [57]. Our study supports the evidence that NF- $\mathrm{kB}$ triggers pro-apoptotic signaling in a subset of NBL cells through Fas upregulation, which tips the scale towards apoptotic cell death.

\section{Conclusions}

The results of this study contribute to our understanding of Fas expression, its regulation by TNF $\alpha$ in a NBL setting, and its implications in the treatment of NBL tumors. Although TNFa is mostly known for its pro-survival signaling $[24,25,28]$, our results indicate that this cytokine has the capacity to prime caspase-8- and Fas-expressing NBLs for cisplatin- and etoposide-induced cell death. These findings pave the way for a new approach to improve clinical response to current NBL treatments.

Table 1 Neuroblastoma characteristics and their modulation by TNFa

\begin{tabular}{|c|c|c|c|c|c|c|c|c|c|}
\hline & & \multicolumn{4}{|c|}{ MYCN non-amplified $[36,37]$} & \multicolumn{4}{|c|}{ MYCN amplified $[36,37]$} \\
\hline & & SK-N-AS & SK-N-SH & CHLA90 & SH-SY5Y & LAI-5S & SK-N-BE(2) & IMR32 & Tet21N \\
\hline \multirow[t]{3}{*}{ Expression } & Fas & + & + & $+/-$ & $+/-$ & - & - & + & ++ \\
\hline & Caspase-8 & ++ & ++ & $+/-$ & - & $+/-$ & $+/-$ & - & ++ \\
\hline & p53 & N [38] & $F[39]$ & $N[40]$ & $F[39]$ & $N[41]$ & $N[40]$ & $F[39]$ & F [39] \\
\hline \multirow[t]{2}{*}{ TNFa-induced } & Fas & ++ & + & + & - & - & - & - & ++ \\
\hline & Sensitization to etoposide/cisplatin & ++ & + & NA & - & - & NA & NA & NA \\
\hline \multirow[t]{2}{*}{ FasL-induced cell death } & UT & + & $+/-$ & - & - & - & - & - & ++ \\
\hline & TNFa & +++ & +++ & + & - & - & - & - & +++ \\
\hline
\end{tabular}

Abbreviations: F Functional, $N$ Non-functional, NA Not available. 


\section{Methods \\ Reagents}

Unless stated otherwise, all biochemical reagents were purchased from Sigma-Aldrich (St. Louis, MO, USA). Recombinant Fc:hFasL was a generous gift of Dr. Pascal Schneider (University of Lausanne, Epalinges, Switzerland). Recombinant human TNF $\alpha$ and IFN $\gamma$ were supplied by Biotrend (Köln, Germany). PD98059, SP600125, BAY 11-7082, Z-IETD-FMK, and Q-VD-OPH were purchased from Merck Millipore (Billerica, MA, USA).

\section{Cell culture}

The human NBL cell lines SK-N-AS, LAI-5S, IMR32, SK-N-BE(2), and SH-SY5Y and the renal epithelial cell line HEK293T were cultured in DMEM (Thermo Fisher Scientific, Waltham, MA, USA) supplemented with $10 \%$ or 15\% (SH-SY5Y) heat-inactivated FBS (FBSi, Thermo Fisher Scientific). The NBL cell lines SK-N-SH and CHLA90 were cultured in IMDM (Thermo Fisher Scientific) supplemented with $20 \% \mathrm{FBSi}$. The NBL cell line Tet $21 \mathrm{~N}$ was maintained in RPMI 1640 (Thermo Fisher Scientific) supplemented with 10\% FBSi, 25 mM HEPES (Thermo Fisher Scientific), $200 \mu \mathrm{g} / \mathrm{ml}$ geneticin (G418), $0.5 \mu \mathrm{g} / \mathrm{ml}$ amphotericin B, and $10 \mu \mathrm{g} / \mathrm{ml}$ hygromycin B. Cell culture media was supplemented with $100 \mathrm{U} / \mathrm{ml}$ penicillin and $100 \mu \mathrm{g} / \mathrm{ml}$ streptomycin (Thermo Fisher Scientific). Cultures were maintained at $37^{\circ} \mathrm{C}$ in a saturated atmosphere of $95 \%$ air and 5\% $\mathrm{CO}_{2}$. CHLA90 cells were acquired from the Children's Oncology Group Cell Line repository. SK-N-BE(2) and LAI-5S cells were from the Public Health England Culture Collections (Salisbury, UK). Tet21N cells were a kind gift from Dr. Manfred Schwab (DKFZ, Heidelberg, Germany). All other cell lines were acquired from the American Type Tissue Collection (ATCC, Manassas, VA, USA).

\section{Hoechst staining}

After the indicated treatments, cells were fixed with $2 \%$ paraformaldehyde, permeabilized with $0.1 \% \operatorname{Triton}^{\text {Tu }} \mathrm{X}-100$, and stained with $0.05 \mu \mathrm{g} / \mathrm{ml}$ Hoechst 33342. Cell death was assessed by counting viable and dead cells, by discriminating condensed and fragmented nuclei (apoptotic nuclear morphology type II), as described by Yuste et al. [58]. Quantification was performed in blind testing, and at least 500 cells were counted per condition.

\section{Caspase activity}

After the indicated treatments, cells were harvested, washed with ice-cold PBS, lysed in caspase activity buffer (20 mM HEPES-NaOH, pH7.2, 10\% sucrose, $150 \mathrm{mM}$ $\mathrm{NaCl}, 5 \mathrm{mM}$ EDTA, 1\% Igepal CA-630, 0.1\% CHAPS, and $1 \times$ EDTA-free Complete protease inhibitor mixture), and insoluble fractions were removed by centrifugation. The protein concentration of the lysate was quantified using the Lowry-based DC protein assay (Biorad, Hercules, CA, USA). Next, caspase activity was assessed by incubating $10 \mu \mathrm{g}$ protein at $37^{\circ} \mathrm{C}$ in caspase activity buffer supplemented with $10 \mathrm{mM}$ DTT and $50 \mu \mathrm{M}$ of the fluorogenic substrate Z-IETD-Afc for caspase-8 activity or Ac-DEVDAfc for caspase-3/7 activity (Merck Millipore). Caspase activity was assessed in a fluorometer using excitation and emission wavelengths of $405 \mathrm{~nm}$ and $535 \mathrm{~nm}$, respectively.

\section{Calcein AM}

After the indicated treatments, cells were incubated for $1 \mathrm{~h}$ at $37^{\circ} \mathrm{C}$ with $1 \mu \mathrm{M}$ Calcein AM (Merck Millipore) diluted in DPBS (Thermo Fisher Scientific). Fluorescence was then assessed in a fluorometer using excitation and emission wavelengths of $485 \mathrm{~nm}$ and $535 \mathrm{~nm}$, respectively.

\section{qRT-PCR}

After treatment, cells were harvested, washed with ice-cold PBS, and RNA was isolated using the RNeasy Mini kit (Qiagen, Hilden, Germany) following the manufacturer's instructions. Next, the RNA was retrotranscribed to cDNA using the High Capacity RNA-to-cDNA ${ }^{\text {tm }}$ Kit (Thermo Fisher Scientific) and subjected to PCR analysis using Taqman $^{\circ}$ probes and Universal PCR Master Mix (Thermo Fisher Scientific). Taqman ${ }^{\circledR}$ probes: Fas (Hs00531110_m1), Caspase-8 (Hs01018151_m1), FADD (Hs00538709_m1), RIP1 (Hs00169407_m1), FasL (Hs00181225_m1), c-FLIP (Hs01116280_m1), Bcl-2 (Hs00608023_m1), and $18 \mathrm{~S}$ (Hs03928990_g1).

\section{Cell surface biotinylation}

Cell surface proteins were biotinylated, isolated, and collected by using the Pierce ${ }^{\oplus}$ Cell Surface Protein Isolation Kit (Thermo Fisher Scientific), following the manufacturer's instructions, with the only exception of equalizing protein quantity and concentration before immunoprecipitation. Protein levels were determined by Western blot.

\section{DISC immunoprecipitation}

For Fas DISC analysis, cells were treated with Fc:hFasL $(2.5 \mu \mathrm{g} / \mathrm{ml})$ for $30 \mathrm{~min}$. The cells were then washed with ice-cold PBS, harvested, and lysed in ice-cold Triton lysis buffer $(\mathrm{NaCl} 150 \mathrm{mM}$, EDTA $10 \mathrm{mM}$, Tris- $\mathrm{HCl}$ pH7.4 $10 \mathrm{mM}, 1 \%$ Triton $^{\mathrm{TM}} \mathrm{X}-100,1 \mathrm{x}$ EDTA-free complete protease inhibitor cocktail (Roche, Basel, Switzerland)). After lysate clearance by centrifugation, Fc:hFasL was immunoprecipitated from the supernatant by incubation with protein G-Sepharose beads for $1 \mathrm{~h}$ on an orbital shaker at $4^{\circ} \mathrm{C}$. Next, the beads were washed $5 \mathrm{x}$ with icecold Triton lysis buffer, and the immunocomplexes were collected with elution buffer (Citrate $0.1 \mathrm{M}, \mathrm{pH} 2.5$ ). The $\mathrm{pH}$ was adjusted by adding $1 / 6$ neutralizing buffer (Tris $\mathrm{HCl} 1 \mathrm{M}, \mathrm{pH} 8.5$ ). Protein levels were determined by Western blot. 


\section{Western blot}

Cells were harvested, washed with ice-cold PBS, and lysed in ice-cold Triton lysis buffer or boiling SET buffer (Tris$\mathrm{HCl}$ pH7.4 10 mM, EDTA 1 mM, NaCl 150 mM, 1\% SDS). Insoluble fractions were removed by centrifugation, and protein concentration of the supernatant was quantified. The cell lysates obtained ( $25 \mu \mathrm{g}$ of protein) were resolved in SDS-polyacrylamide gels. Next, proteins were transferred onto PVDF Immobilon-P membranes (Merck Millipore) by electrophoresis. Membranes were blocked with $5 \%$ non-fat dry milk in $1 \times$ TBS and $0.1 \%$ Tween-20 and probed with the appropriate primary antibodies [anti-Fas (C-20), anti-FADD (S-18), anti-c-FLIP $/ \mathrm{L}(\mathrm{H}-202)$,

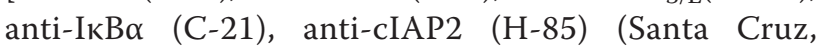
Biotechnology, Santa Cruz, CA, USA), anti- $\alpha$-Tubulin (Sigma-Aldrich), anti-Bcl-2 (Dako, Agilent Technologies, Santa Clara, CA, USA), anti-Caspase-3 and anti-Caspase-8 (Cell Signaling Technologies, Beverly, MA, USA)] and the corresponding peroxidase-conjugated secondary antibodies (Sigma-Aldrich).

\section{Plasmids}

The Super-repressor $\mathrm{I} \kappa \mathrm{B} \alpha$ (SR) cDNA was subcloned from the validated pcDNA3 expression vector [22,59] into the lentiviral pWPI expression vector. SR was expressed under the control of the constitutively active EF-1 Alpha promoter.

\section{Lentiviral production and cell infection}

Lentiviruses were produced in HEK293T cells by Lipofectamine 2000 (Thermo Fisher Scientific) co-transfection of pWPI-derived constructs, pSPAX2, and pM2G in a 3:2:1 ratio, respectively. Cells were allowed to generate lentiviruses for $48 \mathrm{~h}$, after which the lentivirus-bearing medium was collected and passed through a Whatman ${ }^{\circledR} 45 \mu \mathrm{m}$ filter (GE Healthcare, Little Chalfont, UK). For infection, the lentivirus-bearing medium was added to the host cells in combination with $8 \mu \mathrm{g} / \mathrm{ml}$ polybrene. Infection efficiency was assessed by direct counting of GFP-positive cells, and infection was repeated until an efficiency of $\geq 95 \%$ was reached.

\section{Flow cytometry}

After the indicated treatments, cells were detached with cell dissociation buffer (PBS, 5 mM EDTA), harvested, washed $2 \times$ with ice-cold PBS and $1 \times$ with ice-cold FACS buffer (PBS, 2\% FBSi, $0.02 \%$ sodium azide), and then incubated for $30 \mathrm{~min}$ on ice with a PE-conjugated monoclonal antibody against Fas or its matched isotype (Becton Dickinson, Franklin Lakes, NJ, USA). Thereafter, cells were washed $2 \times$ and resuspended in ice-cold FACS buffer. Fas expression was assessed by a FACSCalibur ${ }^{\mathrm{TM}}$ flow cytometer (Becton Dickinson).

\section{Statistical analysis}

All the experiments were repeated at least three times. Values are expressed as mean \pm SD. Statistical significance was determined by one-way or two-way ANOVA using GraphPad Prism v5 (GraphPad Software, La Jolla, CA, USA).

\section{Additional files}

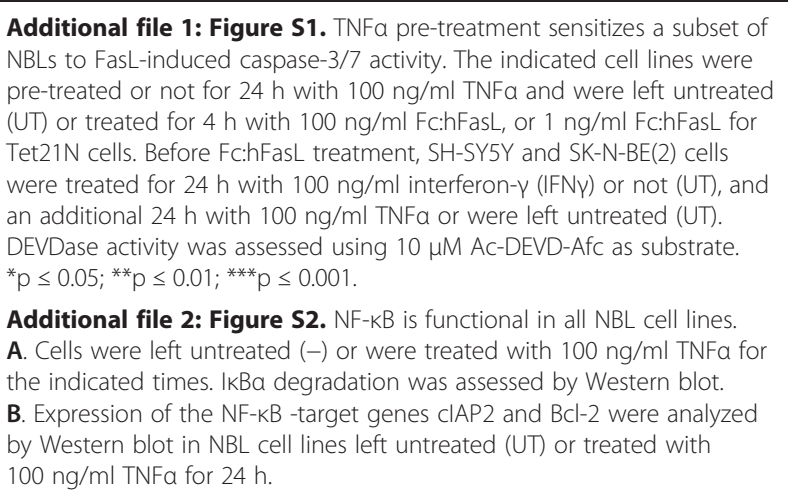

Competing interests

The authors declare that they have no competing interests.

\section{Authors' contributions}

$J X C, M F S$, and KMOG designed the experiments. KMOG, PC, LP-F, JU, EC, JL-S, and RSM performed the laboratory work and collected the data. KMOG, JXC, and MFS analyzed and interpreted the data. KMOG, MFS, JXC, and BB-Z wrote the manuscript. The final manuscript was read and approved by all signing authors

\section{Acknowledgements}

We thank Dr. Pascal Schneider for providing the recombinant Fc:hFasL and Dr. Manfred Schwab for supplying us with the Tet $21 \mathrm{~N}$ cell line. This work was funded by the Spanish Government's "Ministerio de Economía y Competitividad" (SAF2010-19953, SAF2013-47989-R, CIBERNED CB06/05/1104 and PIE13/00027, to JXC), the "Generalitat de Catalunya" (SGR2009-346, 2014SGR1609, to JXC), and the "Instituto de Salud Carlos III" (CP11/00052, RD12/0036/0016, to MFS) co-financed by the European Regional Development Fund (ERDF). KMOG is supported by a postgraduate fellowship which is part of the SAF2010-19953.

Received: 7 October 2014 Accepted: 27 February 2015

Published online: 19 March 2015

\section{References}

1. Brodeur G. Neuroblastoma: biological insights into a clinical enigma. Nat Rev Cancer. 2003;3:203-16.

2. Maris J. Medical progress: recent advances in neuroblastoma. N Engl J Med. 2010;362:2202-11.

3. Maris J, Hogarty M, Bagatell R, Cohn S. Neuroblastoma. Lancet. 2007;369:2106-20.

4. Roos WP, Kaina B. DNA damage-induced cell death by apoptosis. Trends Mol Med. 2006;12:440-50.

5. Cabal-Hierro L, Lazo PS. Signal transduction by tumor necrosis factor receptors. Cell Signal. 2012;24:1297-305.

6. Guicciardi ME, Gores GJ. Life and death by death receptors. FASEB J. 2009;23:1625-37.

7. Linkermann A, Green DR. Necroptosis. N Engl J Med. 2014;370:455-65.

8. Micheau O, Shirley S, Dufour F. Death receptors as targets in cancer. Br J Pharmacol. 2013;169:1723-44. 
9. Russo M, Mupo A, Spagnuolo C, Russo GL. Exploring death receptor pathways as selective targets in cancer therapy. Biochem Pharmacol. 2010;80:674-82.

10. Martin-Villalba A, Llorens-Bobadilla E, Wollny D. CD95 in cancer: tool or target? Trends Mol Med. 2013;19:329-35.

11. Grau E, Martinez F, Orellana C, Canete A, Yanez Y, Oltra S, et al. Hypermethylation of apoptotic genes as independent prognostic factor in neuroblastoma disease. Mol Carcinog. 2011;50:153-62.

12. Teitz T, Wei T, Valentine MB, Vanin EF, Grenet J, Valentine VA, et al. Caspase 8 is deleted or silenced preferentially in childhood neuroblastomas with amplification of MYCN. Nat Med. 2000;6:529-35.

13. Harada K, Toyooka S, Shivapurkar N, Maitra A, Reddy JL, Matta H, et al. Deregulation of caspase 8 and 10 expression in pediatric tumors and cell lines. Cancer Res. 2002;62:5897-901.

14. Teitz T, Lahti JM, Kidd VJ. Aggressive childhood neuroblastomas do not express caspase-8: an important component of programmed cell death. J Mol Med. 2001;79:428-36.

15. Rauert H, Stuehmer T, Bargou R, Wajant H, Siegmund D. TNFR1 and TNFR2 regulate the extrinsic apoptotic pathway in myeloma cells by multiple mechanisms. Cell Death Dis. 2011;2:e194.

16. Borset M, Hjorth-Hansen H, Johnsen AC, Seidel C, Waage A, Espevik T, et al. Apoptosis, proliferation and NF-kappa B activation induced by agonistic Fas antibodies in the human myeloma cell line $\mathrm{OH}-2$ : amplification of Fas-mediated apoptosis by tumor necrosis factor. Eur J Haematol. 1999;63:345-53.

17. Tsuboi M, Kawakami A, Nakashima T, Matsuoka N, Urayama S, Kawabe Y, et al. Tumor necrosis factor-alpha and interleukin-1 beta increase the Fas-mediated apoptosis of human osteoblasts. J Lab Clin Med. 1999;134:222-31.

18. Grell M, Douni E, Wajant H, Lohden M, Clauss M, Maxeiner B, et al. The transmembrane form of tumor-necrosis-factor is the prime activating ligand of the 80 KDA tumor-necrosis-factor receptor. Cell. 1995;83:793-802.

19. Grell M, Wajant H, Zimmermann G, Scheurich P. The type 1 receptor (CD120a) is the high-affinity receptor for soluble tumor necrosis factor Proc Natl Acad Sci U S A. 1998;95:570-5.

20. Holler N, Tardivel A, Kovacsovics-Bankowski M, Hertig S, Gaide O, Martinon F, et al. Two adjacent trimeric Fas ligands are required for Fas signaling and formation of a death-inducing signaling complex. Mol Cell Biol. 2003;23:1428-40.

21. So T, Croft M. Regulation of PI-3-Kinase and Akt Signaling in T Lymphocytes and Other Cells by TNFR Family Molecules. Front Immunol. 2013:4:139.

22. Marques-Fernandez F, Planells-Ferrer L, Gozzelino R, Galenkamp KMO, Reix S, Llecha-Cano N, et al. TNF alpha induces survival through the FLIP-L-dependent activation of the MAPK/ERK pathway. Cell Death Dis. 2013:4:12

23. Rodriguez MS, Wright J, Thompson J, Thomas D, Baleux F, Virelizier JL, et al. Identification of lysine residues required for signal-induced ubiquitination and degradation of I kappa B-alpha in vivo. Oncogene. 1996;12:2425-35.

24. Catz SD, Johnson JL. Transcriptional regulation of bcl-2 by nuclear factor kappa B and its significance in prostate cancer. Oncogene. 2001;20:7342-51.

25. Micheau O, Lens S, Gaide O, Alevizopoulos K, Tschopp J. NF-kappa B signals induce the expression of c-FLIP. Mol Cell Biol. 2001:21:5299-305.

26. Jian S, Song MJ, Shin EC, Lee MO, Kim SJ, Park JH. Apoptosis in human hepatoma cell lines by chemotherapeutic drugs via Fas-dependent and Fas-independent pathways. Hepatology. 1999;29:101-10.

27. Fulda S, Sieverts H, Friesen C, Herr I, Debatin KM. The CD95 (APO-1/Fas) system mediates drug-induced apoptosis in neuroblastoma cells. Cancer Res. 1997:57:3823-9.

28. Chu ZL, McKinsey TA, Liu L, Gentry JJ, Malim MH, Ballard DW. Suppression of tumor necrosis factor-induced cell death by inhibitor of apoptosis C-IAP2 is under NF-kappa B control. Proc Natl Acad Sci U S A. 1997:94:10057-62.

29. Fulda S, Debatin KM. IFN gamma sensitizes for apoptosis by upregulating caspase-8 expression through the Stat1 pathway. Oncogene. 2002;21:2295-308,

30. Lutz W, Fulda S, Jeremias I, Debatin KM, Schwab M. MycN and IFN gamma cooperate in apoptosis of human neuroblastoma cells. Oncogene. 1998;17:339-46.

31. Bernassola F, Scheuerpflug C, Herr I, Krammer PH, Debatin KM, Melino G. Induction of apoptosis by IFN gamma in human neuroblastoma cell lines through the CD95/CD95L autocrine circuit. Cell Death Differ. 1999;6:652-60.

32. Chan H, Bartos DP, Owen-Schaub LB. Activation-dependent transcriptional regulation of the human fas promoter requires NF-kappa B p50-p65 recruitment. Mol Cell Biol. 1999;19:2098-108.
33. Liu FY, Bardhan K, Yang DF, Thangaraju M, Ganapathy V, Waller J L, et al. NF-kappa B Directly regulates Fas Transcription to modulate Fas-mediated Apoptosis and tumor suppression. J Biol Chem. 2012;287:25530-40.

34. Benedetti G, Fredriksson L, Herpers B, Meerman J, van de Water B, de Graauw M. TNF-alpha-mediated NF-kappa B survival signaling impairment by cisplatiri enhances JNK activation allowing synergistic apoptosis of renal proximal tubular cells. Biochem Pharmacol. 2013;85:274-86.

35. Benedetti G, Fokkelman M, Yan K, Fredriksson L, Herpers B, Meerman J, et al. The nuclear factor kappa B family member RelB facilitates apoptosis of renal epithelial cells caused by cisplatin/tumor necrosis factor alpha synergy by suppressing an epithelial to mesenchymal transition-like phenotypic switchs. Mol Pharmacol. 2013:84:128-38.

36. Keshelava N, Seeger RC, Groshen S, Reynolds CP. Drug resistance patterns of human neuroblastoma cell lines derived from patients at different phases of therapy. Cancer Res. 1998;58:5396-405.

37. Thiele CJ. Neuroblastoma. In: Lancaster MJ, editor. Human cell culture, vol. 1. UK: Kluwer Academic Publishers; 1998. p. 21-53.

38. Nakamura Y, Ozaki T, Niizuma H, Ohira M, Kamijo T, Nakagawara A. Functional characterization of a new p53 mutant generated by homozygous deletion in a neuroblastoma cell line. Biochem Biophys Res Commun. 2007:354:892-8.

39. Tweddle DA, Malcolm AJ, Cole M, Pearson ADJ, Lunec J. p53 Cellular localization and function in neuroblastoma - evidence for defective $\mathrm{G}(1)$ arrest despite WAF1 induction in MYCN-amplified cells. Am J Pathol. 2001;158:2067-77.

40. Keshelava N, Zuo JJ, Chen P, Waidyaratne SN, Luna MC, Gomer CJ, et al. Loss of p53 function confers high-level multidrug resistance in neuroblastoma cell lines'. Cancer Res. 2001:61:6185-93.

41. Davidoff AM, Pence JC, Shorter NA, Iglehart JD, Marks JR. Expression of P53 in human neuroblastoma-derived and neuroepithelioma-derived cell-lines. Oncogene. 1992;7:127-33.

42. Oeckinghaus A, Hayden MS, Ghosh S. Crosstalk in NF-kappa B signaling pathways. Nat Immunol. 2011;12:695-708.

43. Decock A, Ongenaert M, Hoebeeck J, De Preter K, Van Peer G, Van Criekinge W, et al. Genome-wide promoter methylation analysis in neuroblastoma identifies prognostic methylation biomarkers. Genome Biol. 2012;13:R95.

44. Petak I, Danam RP, Tillman DM, Vernes R, Howell SR, Berczi L, et al. Hypermethylation of the gene promoter and enhancer region can regulate Fas expression and sensitivity in colon carcinoma. Cell Death Differ. 2003;10:211-7.

45. Santourlidis S, Warskulat U, Florl AR, Maas S, Pulte T, Fischer J, et al. Hypermethylation of the tumor necrosis factor receptor superfamily 6 (APT1, Fas, CD95/Apo-1) gene promoter at rel/nuclear factor kappa B sites in prostatic carcinoma. Mol Carcinog. 2001;32:36-43.

46. Kim S, Kang JH, Evers BM, Chung DH. Interferon-gamma induces caspase-8 in neuroblastomas without affecting methylation of caspase-8 promoter J Pediatr Surg. 2004;39:509-15.

47. Casciano I, Banelli B, Croce M, De Ambrosis A, Di Vinci A, Gelvi I, et al. Caspase-8 gene expression in neuroblastoma. Signal Transduct Commun Cancer Cells. 2004;1028:157-67.

48. Hemmerle T, Probst P, Giovannoni L, Green AJ, Meyer T, Neri D. The antibody-based targeted delivery of TNF in combination with doxorubicin eradicates sarcomas in mice and confers protective immunity. Br J Cancer. 2013;109:1206-13.

49. Papadia F, Basso V, Patuzzo R, Maurichi A, Di Florio A, Zardi L, et al. Isolated limb perfusion with the tumor-targeting human monoclonal antibody cytokine fusion protein L19-TNF plus melphalan and mild hyperthermia in patients with locally advanced extremity melanoma. J Surg Oncol. 2013;107:173-9.

50. Gerspach J, Pfizenmaier K, Wajant H. Improving TNF as a cancer therapeutic: tailor-made TNF fusion proteins with conserved antitumor activity and reduced systemic side effects. Biofactors. 2009;35:364-72.

51. Spitaleri G, Berardi R, Pierantoni C, De Pas T, Noberasco C, Libbra C, et al. Phase $1 /$ II study of the tumour-targeting human monoclonal antibodycytokine fusion protein L19-TNF in patients with advanced solid tumours. J Cancer Res Clin Oncol. 2013;139:447-55.

52. Ferrari S, Casali PG, Blay JY, Tonini G, Le Cesne A, Ali N, et al. Two doses of NGR-hTNF (N) given alone or in combination with doxorubicin (D) in soft tissue sarcomas (STS). J Clin Oncol. 2013;31:1.

53. Perkins ND. The diverse and complex roles of NF-kappa B subunits in cancer. Nat Rev Cancer. 2012;12:121-32. 
54. Hoesel B, Schmid JA. The complexity of NF-kappa B signaling in inflammation and cancer. Mol Cancer. 2013;12:86.

55. Shou Y, Li NY, Li L, Borowitz JL, Isom GE. NF-kappa B-mediated upregulation of $\mathrm{BCl}-\mathrm{X}-\mathrm{S}$ and $\mathrm{Bax}$ contributes to cytochrome $\mathrm{c}$ release in cyanide-induced apoptosis. J Neurochem. 2002;81:842-52.

56. Shetty S, Graham BA, Brown JG, Hu XJ, Vegh-Yarema N, Harding G, et al. Transcription factor NF-kappa B differentially regulates death receptor 5 expression involving histone deacetylase 1. Mol Cell Biol. 2005;25:5404-16.

57. Kasof GM, Lu JJ, Liu DR, Speer B, Mongan KN, Gomes BC, et al. Tumor necrosis factor-alpha induces the expression of DR6, a member of the TNF receptor family, through activation of NF-kappa B. Oncogene. 2001;20:7965-75.

58. Yuste VJ, Bayascas JR, Llecha N, Sanchez-Lopez I, Boix J, Comella JX. The absence of oligonucleosomal DNA fragmentation during apoptosis of IMR-5 neuroblastoma cells - disappearance of the caspase-activated DNase. J Biol Chem. 2001:276:22323-31.

59. Sole C, Dolcet X, Segura MF, Gutierrez H, Diaz-Meco MT, Gozzelino R, et al. The death receptor antagonist FAIM promotes neurite outgrowth by a mechanism that depends on ERK and NF-kappa B signaling. J Cell Biol. 2004;167:479-92.

\section{Submit your next manuscript to BioMed Central and take full advantage of:}

- Convenient online submission

- Thorough peer review

- No space constraints or color figure charges

- Immediate publication on acceptance

- Inclusion in PubMed, CAS, Scopus and Google Scholar

- Research which is freely available for redistribution 